\title{
Effect of Vitamin D deficiency in lower extremity and pulmonary venous thromboembolism
}

\author{
Khatereh Dehghani ${ }^{1}$, Aygin Nowrouzi ${ }^{2}$, Amir Hossein Pourdavood ${ }^{3}$, Zhila Rahmanian ${ }^{4}, *$
}

${ }^{1}$ Department of Cardiology, Jahrom University of Medical Science, Jahrom, Iran

${ }^{2}$ Medical Student of Research Committee, Jahrom University of Medical Science, Jahrom, Iran

${ }^{3}$ Department of Surgery, Kerman University of Medical Science, Kerman, Iran

${ }^{4}$ Department of Internal Medicine, Jahrom University of Medical Science, Jahrom, Iran

\section{Correspondence}

Zhila Rahmanian, Department of Internal Medicine, Jahrom University of Medical Science, Jahrom, Iran

Email: zhilarahmanian@gmail.com

History

- Received: Jan 01, 2019

- Accepted: Mar 18, 2019

- Published: April 29, 2019

DOI :

https://doi.org/10.15419/bmrat.v6i4.535

\section{Check for updates}

\section{Copyright}

(c) Biomedpress. This is an openaccess article distributed under the terms of the Creative Commons Attribution 4.0 International license.

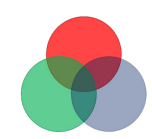

\begin{abstract}
Introduction: Vitamin D deficiency increases inflammation and dysfunction of pancreas betacells, resulting in atherosclerotic disorders, cerebrovascular disorder, and CVDs. Methods: In the present cross-sectional study, vitamin D was evaluated in the plasma of 42 patients with lower extremity DVT or PE, as well as 42 healthy controls. Using the chemiluminescence assay, the plasma vitamin D levels were determined. After collection, the blood samples were examined within 60 minutes. Vitamin D levels were classified as sufficient, insufficient, and deficient (>30 ng/mL, 20$29 \mathrm{ng} / \mathrm{mL}$, and $<20 \mathrm{ng} / \mathrm{mL}$, respectively). Results: The prevalence of deficiency in vitamin D was higher in the cases than the controls. The two groups were significantly different regarding vitamin $D$ levels $(p=0.024)$. Based on the vitamin D classification, deficiency was reported in $30(71.4 \%)$ patients and 18 (42.9\%) controls. Conclusion: Our findings indicated that VTE patients had lower concentration of vitamin D, and the correlation between VTE and vitamin D deficiency was confirmed.
\end{abstract}

Key words: Deficiency, PTE, vitamin D, VTE

\section{INTRODUCTION}

Vitamin D is recognized as a major factor in human health, which includes preventing osteoporosis and osteomalacia in adults, as well as rickets in children. Vitamin D is traditionally known to decrease the risk of cardiovascular diseases (CVDs), cancers, and chronic disorders ${ }^{1-4}$. On the other hand, vitamin $D$ deficiency increases inflammation and dysfunction of pancreas beta-cells, resulting in atherosclerotic disorders, cerebrovascular disorder, and CVDs ${ }^{5-8}$.

Deficiency in vitamin D is characterized by a plasma 25-hydroxyvitamin D concentration lower than 20 $\mathrm{ng} / \mathrm{mL}$. It is described as a common global problem with a prevalence of $30-50 \%$ population ${ }^{3,4}$, and is involved in CVDs and venous thromboembolism (VTE) ${ }^{5,6,9-11}$. In leukemic patients, active vitamin D stimulates anticoagulant effects through tissue factor downregulation and thrombomodulin upregulation $^{12-14}$.

Vitamin D receptors are involved in thrombosis ${ }^{15,16}$. On the other hand, VTE is recognized as a common CVD, resulting in morbidity and mortality ${ }^{17}$. Overall, the VTE spectrum, including deep vein thrombosis (DVT) and pulmonary embolism (PE), affects almost 2 per 1000 population ${ }^{18}$. The correlation of vitamin $\mathrm{D}$ deficiency with thromboembolism has been highlighted in multiple studies ${ }^{19,20}$. Based on previous findings, the risk of VTE is reduced with an increase in vitamin D levels ${ }^{9}$. In addition, the use of vitamin $\mathrm{D}$ in patients with prostate cancer reduces the incidence of $\mathrm{DVT}^{9,20}$. Therefore, vitamin $\mathrm{D}$ deficiency increases inflammation and dysfunction of pancreas beta-cells, resulting in atherosclerotic disorders, cerebrovascular disorder, and CVDs. In this study, we aimed to evaluate an association of vitamin D levels, pulmonary and lower extremity venous thromboembolism.

\section{METHODS}

\section{Patients}

In the present cross-sectional study, vitamin D was evaluated in the plasma of patients with lower extremity DVT or PE, as well as healthy controls (age- and sex-matched). The study sample included ICU and CCU patients with suspected DVT or PE, along with patients visiting Honari Clinic (Jahrom, Southwest of Fars Province, Iran) for a routine checkup from June 2016 to June 2017.

The case and control groups included 42 DVT and PE patients and 42 healthy individuals, respectively. The control group did not have any common risk factors for VTE. This study was approved by the Jahrom University of Medical Sciences. Also, for the collection of blood samples, all participants were asked to provide their written informed consents.

A combination of D-dimer test, clinical probability, spiral chest CT scan, and color Doppler ultrasound was applied for the diagnosis of DVT and PE in 6(4):3017-3112. 
patients ${ }^{26}$. The exclusion criteria were as follows: 1) pregnancy; 2) cancer; 3) hormone replacement therapy; 4) chronic renal disease (above stage II) or renal failure; 5) vitamin $\mathrm{D}$ supplementation in the last two years; 6) major trauma or surgery in the last three months; 7) family history of VTE, and 8) positive thrombophilia markers.

Finally, none of the participants was excluded. No signs or symptoms of VTE, VTE history, positive thrombophilia, or vitamin D supplementation were reported in the control group; also, they did not meet the mentioned exclusion criteria. Upon admission, demographic information such as history of hypertension, surgery, obesity, smoking, diabetes mellitus, dyslipidemia, and ischemic heart disease, was collected.

\section{Chemiluminescence assay}

Using the chemiluminescence assay, the plasma vitamin D level was determined. Blood samples were collected and examined within 60 minutes. The vitamin D level was classified as sufficient, insufficient, and deficient (> $30 \mathrm{ng} / \mathrm{mL}, 2-29 \mathrm{ng} / \mathrm{mL}$, and $<20 \mathrm{ng} / \mathrm{mL}$, respectively) ${ }^{1}$.

\section{Statistics analysis}

For statistical analysis, SPSS 21.0 was used, and the significance $p$ value was 0.05 . For the evaluation of categorical variables, Chi square test was performed, while Mann-Whitney U test, Kruskal-Wallis, or student t-tests were applied for examining continuous variables.

\section{RESULTS}

The mean age of the participants was $47.52 \pm 18.31$ years, and the mean vitamin $\mathrm{D}$ concentration was $21.79 \pm 13.73$. Overall, $61.9 \%$ were male and $38.1 \%$ were female. The prevalence of deficiency in vitamin $\mathrm{D}$ was higher in the case group than the controls. The two groups were significantly different regarding vitamin D levels $(p=0.024)$. Based on the vitamin D classification, deficiency was reported in 30 (71.4\%) patients and 18 (42.9\%) controls.

The data analysis in Table 1 revealed a correlation between age, gender, and BMI in the case and control groups, whereas no major intergroup difference was reported.

Based on the Chi-square test, vitamin D was not linked to VTE risk factors, including diabetes, BMI, age, sex, history of surgery, hyperlipidemia, hypertension, smoking, the use of preventive pills, ischemic heart disease, and more than three days of absolute rest $(p>0.05)$.
Deficiency in vitamin D was clinically more frequent in male DVT or PE patients (66.7\%), compared to female counterparts $(33.3 \%)$. In addition, it was more common among patients with diabetes $(13.3 \%)$, history of surgery $(30.0 \%)$, hyperlipidemia $(33.3 \%)$, hypertension $(30.0 \%)$, smoking $(23.3 \%)$, the use of preventive pills (10\%), history of ischemic heart disease (31\%), and patients with absolute rest in more than three days (30\%). Vitamin D deficiency showed the highest rate in overweight cases (50\%) and patients aged $30-60$ years $(56.7 \%)$ (Figure 1 ).

\section{DISCUSSION}

VTE is recognized as the third most common CVD associated with mortality. According to a previous meta-analysis, vitamin D deficiency increased allcause mortality besides CVD and cancer-related mortality $^{21}$

Our findings indicated that VTE patients had lower concentrations of vitamin $\mathrm{D}$, and the correlation between VTE and vitamin D deficiency was confirmed. The prevalence of deficiency in vitamin $\mathrm{D}$ was higher in the cases than the controls. The two groups were significantly different regarding vitamin $\mathrm{D}$ level $(p=$ 0.024). Based on the vitamin D classification, deficiency was reported in $30(71.4 \%)$ patients from the case group and 18 (42.9\%) controls. The prevalence of vitamin D deficiency among male and female PTE patients were 66.7 and $33.3 \%$, respectively $(p=0.273)$. Overall, healthy female adults had more Vitamin D deficiency in Iranian population. This subject is in contrast with our study on PTE patients.

In the present study, hypertension was revealed in $70 \%$ of PTE patients with vitamin D deficiency ( $p=$ 0.438). Overall, deficiency in vitamin $D$ is related to the risk of hypertension and CVDs based on observational studies ${ }^{22}$, while most randomized trials have not reported any cardiovascular benefits from vitamin D supplements. However, the main reason for the association between CVDs and vitamin D levels in different patient populations remains uncertain $20,23,24$. According to another meta-analysis, the risk of CVDs was correlated inversely with serum vitamin D in 19 prospective studies ${ }^{25}$. Moreover, in the Framingham Offspring Study, cardiovascular events were more significantly associated with vitamin $\mathrm{D}<15 \mathrm{ng} / \mathrm{mL}$ (vs. $>15 \mathrm{ng} / \mathrm{mL}$ ) during 5.4 years of observation ${ }^{5}$.

As reported in a large survey during 2001-2004, vitamin D levels of less than $20 \mathrm{ng} / \mathrm{mL}$ contributed to a higher risk of coronary heart disease when compared to the levels of $\geq 30 \mathrm{ng} / \mathrm{mL}^{26,27}$. Moreover, Entezari-Maleki et al. ${ }^{28}$ evaluated the risk factors for VTE, hs-CRP, and P-selectin in patients with acute 


\begin{tabular}{lllll}
\hline \multicolumn{4}{l}{ Table 1: Comparison of age, sex, and BMI between the groups } \\
\hline Variable & & Case $\mathrm{n}=42(\%)$ & Control $\mathrm{n}=42(\%)$ & P-value \\
\hline Sex & Male & $26(61.9)$ & $26(61.9)$ & 0.241 \\
& Female & $16(38.1)$ & $16(38.1)$ & 0.99 \\
BMI & Underweight & $1(2.4)$ & 0 & \\
& Normal & $20(47.6)$ & $22(52.4)$ & \\
& Overweight & $18(42.9)$ & $20(47.6)$ & 0.55 \\
& Obese & $3(7.1)$ & 0 & \\
Age & $30>$ & $7(16.7)$ & $11(26.2)$ & \\
& $30-60$ & $25(59.5)$ & $23(54.8)$ & $8(19)$ \\
\hline
\end{tabular}

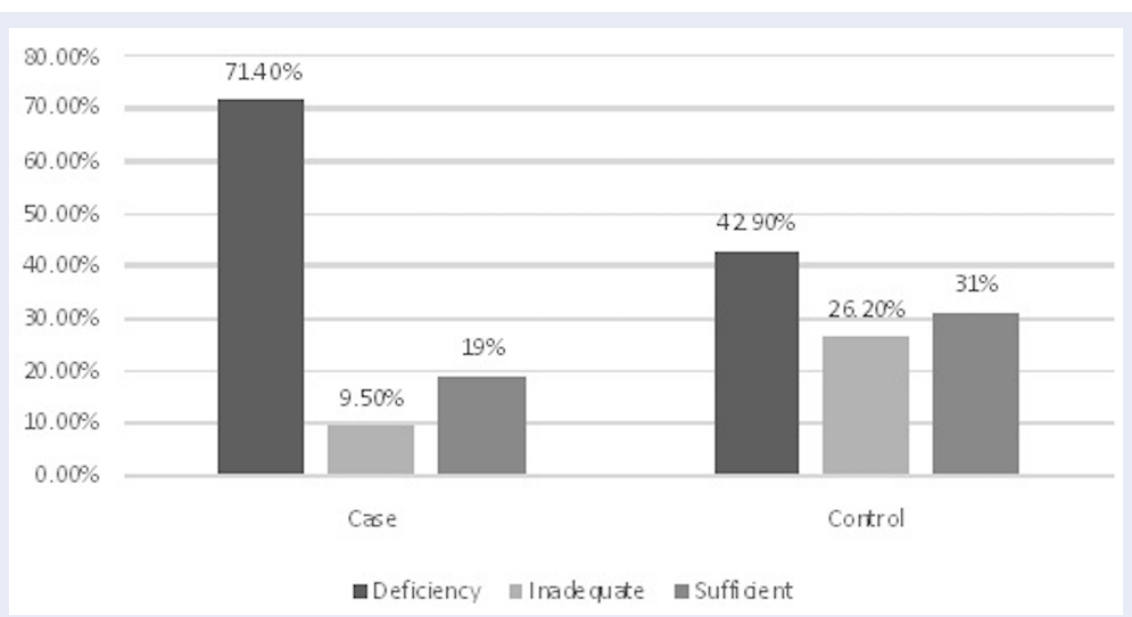

Figure 1: Comparison of the status of vitamin D levels among VTE patients and healthy population.

DVT or PE. The study was conducted on 60 subjects with a vitamin D levels of $21.4 \pm 14.6 \mathrm{ng} / \mathrm{mL}$, which was close to our study $(21.79 \pm 13.73 \mathrm{ng} / \mathrm{mL})$. They indicated the high frequency of vitamin $\mathrm{D}$ deficiency in Iranian VTE patients, which is consistent with our study. Nevertheless, vitamin D levels had no association with age, diabetes, or other risk factors for VTE. Additionally, Khademvatani and colleagues ${ }^{29}$ indicated a significantly lower serum levels of vitamin D in DVT patients in comparison with the controls. It was concluded that idiopathic lower extremity DVT was related to low vitamin D levels, which is consistent with our results. Ohsawa and colleagues ${ }^{13}$ emphasized that tissue and thrombomodelin regulation by analogue $1,25(\mathrm{OH})^{2} \mathrm{D}^{3}$ was accomplished by vitamin $\mathrm{D}$ receptors, and these analogues could be used to treat or prevent atherosclerotic and thrombotic disorders. Therefore, the involvement of vitamin D in thrombosis development was confirmed, which is consistent with our study.

Brøndum-Jacobsen et al. ${ }^{10}$ evaluated the link between VTE and vitamin D among 18791 participants over 30 years. In this extensive study, the increased risk of VTE was attributed to a seasonal decline in vitamin D concentrations; this finding represented the link between VTE and vitamin D deficiency similarly to our study. Another study also reported congruent results with our study, which showed the contribution of vitamin $\mathrm{D}$ to non-age-related coagulability and $\mathrm{BMI}^{30}$.

In 2004, Ken-ichi Aihara and colleagues explored the issue that breakage of the nuclear receptor of vitamin $\mathrm{D}$ would increase thrombogenesis in mice. Based on their findings, vitamin D receptor (VDR) activation induced antithrombotic effects. They also stated that VDR might be involved in the maintenance of antithrombotic homeostasis. The antithrombotic role of 


\begin{tabular}{|c|c|c|c|c|c|}
\hline \multirow[b]{2}{*}{ Risk Factors } & \multicolumn{5}{|c|}{ Vitamin D Level } \\
\hline & & $\begin{array}{l}\text { Deficiency } \\
(\%)\end{array}$ & $\begin{array}{l}\text { Inadequate } \\
(\%)\end{array}$ & Sufficient (\%) & P-Value \\
\hline \multirow[t]{2}{*}{ Diabetes Mellitus } & Positive & $26(86.7)$ & $3(75)$ & $7(87.5)$ & 0.811 \\
\hline & Negative & $4(13.3)$ & $1(25)$ & $1(12.5)$ & \\
\hline \multirow[t]{2}{*}{ Surgery History } & Positive & $21(70)$ & $2(50)$ & $4(50)$ & 0.474 \\
\hline & Negative & $9(30)$ & $2(50)$ & $4(50)$ & \\
\hline \multirow[t]{2}{*}{ Hyperlipidemia } & Positive & $20(66.7)$ & $4(100)$ & $7(87.5)$ & 0.225 \\
\hline & Negative & $10(33.3)$ & 0 & $1(12.5)$ & \\
\hline \multirow[t]{2}{*}{ Hypertension } & Positive & $21(70)$ & $4(100)$ & $6(75)$ & 0.438 \\
\hline & Negative & $9(30)$ & 0() & $2(25)$ & \\
\hline \multirow[t]{2}{*}{ Smoker } & Positive & $23(76.7)$ & $3(75)$ & $6(75)$ & 0.993 \\
\hline & Negative & $7(23.3)$ & $1(25)$ & $2(25)$ & \\
\hline \multirow[t]{2}{*}{ Predictive pill } & Positive & $27(90)$ & $4(100)$ & $6(75)$ & 0.377 \\
\hline & Negative & $3(10)$ & 0 & $2(25)$ & \\
\hline \multirow[t]{2}{*}{ Ischemic Heart Disease } & Positive & $20(69)$ & $3(75)$ & $6(75)$ & 0.928 \\
\hline & Negative & $9(31)$ & $1(25)$ & $2(25)$ & \\
\hline \multirow[t]{2}{*}{ Absolute Rest (More than 3 day) } & Positive & $21(70)$ & $2(50)$ & $4(50)$ & 0.474 \\
\hline & Negative & $9(30)$ & $2(50)$ & $4(50)$ & \\
\hline \multicolumn{2}{|l|}{ Demographic Factor } & \multicolumn{2}{|c|}{ Deficiency(\%) Inadequate(\%) } & Sufficient(\%) & P-Value \\
\hline \multirow[t]{2}{*}{ Sex } & Male & $20(66.7)$ & $3(75)$ & $3(37.5)$ & 0.273 \\
\hline & Female & $10(33.3)$ & $1(25)$ & $5(62.5)$ & \\
\hline \multirow[t]{4}{*}{ BMI } & Underweight & 0 & 0 & $1(12.5)$ & 0.233 \\
\hline & Normal & $12(40)$ & $3(75)$ & $5(62.5)$ & \\
\hline & Overweight & $15(50)$ & $1(25)$ & $2(25)$ & \\
\hline & Obese & $3(10)$ & 0 & 0 & \\
\hline \multirow[t]{3}{*}{ Age } & $30>$ & $5(16.7)$ & 0 & $2(25)$ & 0.505 \\
\hline & $30-60$ & $17(56.7)$ & $4(100)$ & $4(50)$ & \\
\hline & $60<$ & $8(26.7)$ & 0 & $2(25)$ & \\
\hline
\end{tabular}

vitamin D was established in their study, which is consistent with the results of our investigation ${ }^{16}$. In contrast, E Brodin et al. indicated that serum vitamin D was not involved in the pathogenesis or risk of VTE; nevertheless, this finding calls for further research ${ }^{31}$. Generally, the prevalence of CVDs is rising, and it is one of the major causes of VTE and clot formation. Regarding the possible positive connection between CVDs and vitamin D, as reported in the limited literature, the exact correlation between vitamin $\mathrm{D}$ and
VTE should be evaluated in further comprehensive studies.

This study had some limitations. There is increasing evidence in terms of seasonal effects on $25(\mathrm{OH}) \mathrm{D}$ levels and it has been demonstrated that vitamin $\mathrm{D}$ concentration is at its lowest in the winter months compared to summer. However, in our study we could not investigate the seasonal impact on DVT incidence because our study was conducted during the warm months. Prothrombin gene mutation was not 
assessed in this study. The small sample size of our study was another restriction.

\section{CONCLUSIONS}

This study showed that lower extremity and pulmonary venous thromboembolism patients had lower concentrations of vitamin $\mathrm{D}$, and the correlation between VTE and vitamin D deficiency was confirmed.

\author{
ABBREVIATIONS \\ CVD: cardiovascular diseases \\ VTE: Venous Thromboembolism \\ DVT: Deep Vein Thrombosis \\ PE: Pulmonary embolism \\ CCU: Cardiac Care Unit \\ ICU: Intensive Care Unit \\ CT: Computed Tomography \\ VDR: Vitamin D Receptor \\ CRP: C-Reactive Protein
}

\section{CONFLICT OF INTERESTS}

The authors declare that they have no conflicts of Interest.

\section{AUTHORS' CONTRIBUTIONS}

Khatere Dehghani: Design of the study, acquisition of data, and writing of the article. Aygin Nowrouzi: Collection of data and revision of the article. Amir Hossein Pourdavood: Analysis and interpretation of data and revision of the article. Zhila Rahmanian: Design of the study, Revision of the article and final approval of the version to be published.

\section{ACKNOWLEDGMENT}

The authors would like to thank the Research Consulting Center (RCC) of Shiraz University of Medical Science for improving the use of English in the manuscript.

\section{REFERENCES}

1. Holick MF. Vitamin D deficiency. New England Journal of Medicine. 2007;357(3):266-81. 17634462. Available from: 10.1056/NEJMra070553.

2. Holick MF, Chen TC. Vitamin D deficiency: a worldwide problem with health consequences-. The American journal of clinical. 2008;87(4):1080S-6S. 18400738. Available from: 10.1093/ ajcn/87.4.1080S.

3. Anderson JL, May HT, Horne BD, Bair TL, Hall NL, Carlquist JF. Relation of vitamin $D$ deficiency to cardiovascular risk factors, disease status, and incident events in a general healthcare population. The American journal of cardiology. 2010;106(7):963-8. 20854958. Available from: 10.1016/j. amjcard.2010.05.027.

4. Vacek JL, Vanga SR, Good M, Lai SM, Lakkireddy D, Howard PA. Vitamin D deficiency and supplementation and relation to cardiovascular health. The American journal of cardiology. 2012;109(3):359-63. 22071212. Available from: 10.1016/j. amjcard.2011.09.020
5. Wang TJ, Pencina MJ, Booth SL, Jacques PF, Ingelsson E, Lanier $\mathrm{K}$, et al. Vitamin D deficiency and risk of cardiovascular disease. Circulation. 2008;117(4):503-11. 18180395. Available from: 10.1161/CIRCULATIONAHA.107.706127.

6. Lee JH, O'Keefe JH, Bell D, Hensrud DD, Holick MF. Vitamin D deficiency: an important, common, and easily treatable cardiovascular risk factor? Journal of the American College of Cardiology. 2008;52(24):1949-56. 19055985. Available from: 10.1016/j.jacc.2008.08.050.

7. Pilz S, Dobnig H, Fischer JE, Wellnitz B, Seelhorst U, Boehm BO, et al. Low vitamin $D$ levels predict stroke in patients referred to coronary angiography. Stroke. 2008;39(9):2611-3. 18635847. Available from: 10.1161/STROKEAHA.107.513655.

8. Kojima G, Bell C, Abbott RD, Launer L, Chen R, Motonaga $\mathrm{H}$, et al. Low dietary vitamin $\mathrm{D}$ predicts 34-year incident stroke: the Honolulu Heart Program. Stroke. 2012;43(8):21637. 22627988. Available from: 10.1161/STROKEAHA.112. 651752.

9. Lindqvist PG, Epstein E, Olsson H. Does an active sun exposure habit lower the risk of venous thrombotic events? ADlightful hypothesis. Journal of Thrombosis and Haemostasis. 2009;7(4):605-10. 19335448. Available from: 10.1111/j.15387836.2009.03312.x.

10. Brøndum-Jacobsen P, Benn M, Tybjaerg-Hansen A, Nordestgaard B. 25-Hydroxyvitamin D concentrations and risk of venous thromboembolism in the general population with 18 791 participants. Journal of Thrombosis and Haemostasis. 2013;11(3):423-31. 23279309. Available from: 10.1111/jth. 12118.

11. Pilz S, Tomaschitz A, März W, Drechsler C, Ritz E, Zittermann A, et al. Vitamin D, cardiovascular disease and mortality. Clinical endocrinology. 2011;75(5):575-84. 21682758. Available from: 10.1111/j.1365-2265.2011.04147.x.

12. Maillard C, Berruyer M, Serre CM, Amiral J, Dechavanne M, Delmas PD. Thrombomodulin is synthesized by osteoblasts, stimulated by $1,25-(\mathrm{OH}) 2 \mathrm{D} 3$ and activates protein $\mathrm{C}$ at their cell membrane. Endocrinology. 1993;133(2):668-74. 8393772. Available from: 10.1210/endo.133.2.8393772.

13. Ohsawa M, Koyama T, Yamamoto K, Hirosawa S, Kamei S, Kamiyama R. $1 \alpha, 25$-dihydroxyvitamin D3 and its potent synthetic analogs downregulate tissue factor and upregulate thrombomodulin expression in monocytic cells, counteracting the effects of tumor necrosis factor and oxidized LDL. Circulation. 2000;102(23):2867-72. 11104746. Available from: 10.1161/01.CIR.102.23.2867.

14. Koyama T, Hirosawa S. Anticoagulant effects of synthetic retinoids and activated vitamin D3. Semin Thromb Hemost. 1998;24(3):217-26. 9701451. Available from: 10.1055/s-2007995845.

15. Wu-Wong JR, Nakane M, Ma J. Vitamin D analogs modulate the expression of plasminogen activator inhibitor1 , thrombospondin-1 and thrombomodulin in human aortic smooth muscle cells. Journal of vascular research. 2007;44(1):11-8. 17159355. Available from: 10.1159/ 000097812 .

16. Aihara $K$, Azuma $H$, Akaike $M$, Ikeda $Y$, Yamashita $M$, Sudo T. Disruption of nuclear vitamin $D$ receptor gene causes enhanced thrombogenicity in mice. Journal of Biological Chemistry. 2004;279(34):35798-802. 15205460. Available from: 10.1074/jbc.M404865200.

17. Prandoni P, Bilora F, Marchiori A, Bernardi E, Petrobelli $F$, Lensing AW. An association between atherosclerosis and venous thrombosis. New England Journal of Medicine. 2003;348(15):1435-41. 12686699. Available from: 10.1056/ NEJMoa022157.

18. Mokhtari M, Salameh P, Kouchek M, Kashani B, Taher A, Waked $M$, et al. The AVAIL ME Extension: a multinational Middle Eastern survey of venous thromboembolism risk and prophylaxis. Journal of Thrombosis and Haemostasis. 2011;9(7):1340-9. 21605327. Available from: 10.1111/j.1538-7836.2011.04336.x. 
19. Agmon-Levin N, Blank M, Zandman-Goddard G, Orbach $\mathrm{H}$, Meroni $P$, Tincani $A$, et al. Vitamin D: an instrumental factor in the anti-phospholipid syndrome by inhibition of tissue factor expression. Annals of the Rheumatic Diseases. 2011;70(1):145-50. 20980705. Available from: 10.1136/ard. 2010.134817.

20. Beer TM, Venner PM, Ryan CW, Petrylak DP, Chatta G, Ruether JD, et al. High dose calcitriol may reduce thrombosis in cancer patients. British journal of haematology. 2006;135(3):392-4. 16984385. Available from: 10.1111/j.1365-2141.2006.06322.x.

21. Schöttker B, Jorde R, Peasey A, Thorand B, Jansen EH, de Groot L. Vitamin D and mortality: meta-analysis of individual participant data from a large consortium of cohort studies from Europe and the United States. Bmj. 2014;348:g3656. 24938302. Available from: $10.1136 / \mathrm{bmj} . \mathrm{g} 3656$.

22. Theodoratou E, Tzoulaki I, Zgaga L, loannidis JP. Vitamin D and multiple health outcomes: umbrella review of systematic reviews and meta-analyses of observational studies and randomised trials. Bmj. 2014;348:g2035. 24690624. Available from: 10.1136/bmj.g2035.

23. Robinson-Cohen C, Hoofnagle AN, Ix JH, Sachs MC, Tracy RP, Siscovick DS. Racial differences in the association of serum 25hydroxyvitamin D concentration with coronary heart disease events. Jama. 2013;310(2):179-88. 23839752. Available from: 10.1001/jama.2013.7228.

24. Norris KC, Williams SF. Race/ethnicity, serum 25hydroxyvitamin D, and heart disease. JAMA. 2013;310(2):1535. 23839748. Available from: 10.1001/jama.2013.7229.

25. Wang L, Song Y, Manson JE, Pilz S, März W, Michaëlsson K, et al. Circulating 25-hydroxy-vitamin D and risk of cardiovascular disease: a meta-analysis of prospective studies. Circulation: Cardiovascular Quality and Outcomes. 2012;CIRCOUTCOMES. 112.967604 .
26. Kim DH, Sabour S, Sagar UN, Adams S, Whellan DJ. Prevalence of hypovitaminosis D in cardiovascular diseases (from the $\mathrm{Na}$ tional Health and Nutrition Examination Survey 2001 to 2004). The American journal of cardiology. 2008;102(11):1540-4. 19026311. Available from: 10.1016/j.amjcard.2008.06.067.

27. Kendrick J, Targher G, Smits G, Chonchol M. 25Hydroxyvitamin D deficiency is independently associated with cardiovascular disease in the Third National Health and Nutrition Examination Survey. Atherosclerosis. 2009;205(1):255-60. 19091317. Available from: 10.1016/j.atherosclerosis.2008.10.033.

28. Entezari-Maleki T, Talasaz AH, Salarifar M, Hadjibabaie $M$, Javadi MR, Bozorgi A. Plasma vitamin D status and its correlation with risk factors of thrombosis, P-selectin and hsCRP level in patients with venous thromboembolism; the first study of Iranian population. Iranian journal of pharmaceutical research: IJPR. 2014;13(1):319. 24734087.

29. Khademvatani K, Seyyed-Mohammadzad MH, Akbari $M$, Rezaei Y, Eskandari R, Rostamzadeh A. The relationship between vitamin D status and idiopathic lower-extremity deep vein thrombosis. International journal of general medicine. 2014;7:303. 24971035.

30. Kebapcilar AG, Kulaksizoglu M, Ipekci SH, Korkmaz H, Kebapcilar L, Akyurek F, et al. Relationship between mean platelet volume and low-grade systemic coagulation with vitamin D deficiency in primary ovarian insufficiency. Archives of Gynecology and Obstetrics. 2013;288(1):207-12. 23377179. Available from: 10.1007/s00404-013-2735-x.

31. Brodin EE, Lerstad G, Grimnes G, Brækkan SK, Vik A, Brox J, et al. Serum levels of vitamin $D$ are not associated with future risk of venous thromboembolism. Thrombosis and haemostasis. 2013;110(05):885-90. 23446951. Available from: 10.1160/ TH12-10-0728. 